Limnol. Rev. (2014) 14,2: 93-100

\title{
Anthropogenic change in water bodies in the southern part of the Silesian Upland
}

\author{
Robert Machowski, Marek Noculak \\ Department of Physical Geography, Faculty of Earth Sciences, University of Silesia, Będzińska 60, 41-200 Sosnowiec, \\ ^e-mail: robert.machowski@us.edu.pl (corresponding author)
}

\begin{abstract}
The paper analyses the anthropogenic change in water bodies in the southern part of the Silesian Upland as exemplified by the town of Knurów. The assessment was based on topographic maps from the years 1827-1828, 1928-1936, 1960 and 1993, and on a 2011 orthophotomap. The cartographic materials used were processed as required for analysis purposes. Maps were calibrated in the Quantum GIS program on the basis of map corner coordinates and using the common points method. In Knurów, four main types of water bodies were distinguished with respect to their origins: reservoirs impounded by dams, flooded mineral workings, industrial water bodies and water bodies in subsidence basins and hollows. Historically, the first water bodies to appear were reservoirs impounded by dams, which dominated until the 1930s. They later fell into disuse and were completely dismantled. Water bodies in mineral workings formed in the early $20^{\text {th }}$ century and were associated with the excavation of raw materials for producing bricks. The period of their greatest significance were the 1960s, when they constituted slightly more than $46 \%$ of water bodies in total and accounted for nearly $40 \%$ of overall surface area. At the end of the $19^{\text {th }}$ and at the beginning of the $20^{\text {th }}$ century, industrial reservoirs began to appear. Within the town of Knurów, those were sedimentation tanks that held mine water, washery effluent, backfill and cooling water, fire-fighting water pools and tanks, tanks at sewage treatment plants, industrial water tanks and others. Presently, these account for $41.4 \%$ (29) of the total number of water bodies and have a total surface area of 32.0 ha $(25,2 \%)$. Within the study area, water bodies in subsidence basins and hollows only began to form in the second half of the $20^{\text {th }}$ century. In 2011, such water bodies numbered 38 (54.3\%) and occupied an area of 90.4 ha $(71.2 \%)$.
\end{abstract}

Key words: Silesian Upland, water reservoirs, anthropopressure, limnology.

\section{Introduction}

Of all regions in Poland, the Silesian Upland has undergone the greatest transformation in terms of its natural environment, which has been caused by human economic activity. The decisive factor in this respect was industrialisation (considerable concentration of multiple branches of industry and mining) and the related urbanisation process. This caused an influx of large numbers of people into the area. Broadly defined human pressure affected all elements of the natural environment: the atmosphere, lithosphere, pedosphere, hydrosphere and biosphere. As a result of economic activity, many different types of artificial landforms emerged within the Silesian Upland. Among them, both convex (slag and other types of heaps, embankments, mounds, etc.) and concave (mineral workings, trenches, subsidence basins and hollows, etc.) forms can be found; the latter is filled with water in many cases (Jankowski 1986; Czaja 1999; Pełka-Gościniak 2006; Rzętała 2008; Machowski 2010; Dulias 2011, Rzętała and Jaguś 2012). The peculiar natural environment of the Silesian Upland, which has been affected by human activity, reveals many characteristic features that are directly related to changes in water conditions. Anthropogenic water bodies, which are numerous in this area, play an important role in shaping these conditions. The paper analyses anthropogenic change in water bodies in the southern part of the Silesian Upland as exemplified by the town of Knurów.

\section{Methods}

This analysis necessitated detailed indoor studies, which were complemented by field mapping. Both 
archival and contemporary topographic maps as well as orthophotomaps were the primary tools used for study purposes. The time range covered around two hundred years from the first half of the $19^{\text {th }}$ century until the early 2010s. The earliest Prussian maps that covered the area in question were published in 1827 and 1828 (Urmasstischblatt Bande). Subsequent maps used in the study were published from 1928 to 1936 (Topographische Karte Prov. Oberschlesien). There was also a 1960 topographic map of the Upper Silesian Industrial Region (so-called "obrębówka" or district-level map); a 1993 topographic map of the city of Gliwice (M-34-62-A) and its vicinity was used as well. A modern image of Knurów was obtained from aerial photographs that were processed to obtain an orthophotomap. This material dates from May 2011. The cartographic materials used were processed as required for analysis purposes. Base maps were calibrated in the Quantum GIS program on the basis of map corner coordinates and using the common points method in order to impose a single coordinate system on the maps PUWG 1992. In order to verify the figures, hydrological mapping was conducted, which involved not only drawing up an inventory of water bodies but also classifying them in terms of their origins. The analysis included all water bodies, regardless of the surface occupied by them.

\section{Study area}

The study covered Knurów within its contemporary administrative boundaries, i.e. an area of 33.95 $\mathrm{km}^{2}$. The study area is situated in the southern part of the Silesian Upland and extends from $18^{\circ} 36^{\prime} 45^{\prime \prime}$ to $18^{\circ} 42^{\prime} 49^{\prime \prime}$ East longitude and from $50^{\circ} 10^{\prime} 22^{\prime \prime}$ to $50^{\circ} 14^{\prime} 26^{\prime \prime}$ North latitude. Another way to describe the location of the town is to place it with respect to the physiogeographical units distinguished by Kondracki (2002). The town area lies within two mesoregions: the Katowice Upland (341.13) and the Rybnik Plateau (341.15), both of which form parts of the Silesian Upland (341.1) macro-region. The boundary between these mesoregions runs from the west towards the southeast along the Bierawka River. The greater part of the town lies within the south-western part of the Katowice Upland, while the remaining area is included in the northern part of the Rybnik Plateau (Fig. 1).

The deep substrate in this area consists primarily of Carboniferous rocks, among which the most important are Upper Carboniferous formations: sand- stones, claystones, mudstones and coal beds. Carboniferous deposits are usually covered by impermeable Paleogene and Neogene rock layers (clays and muds), which impede the infiltration of rainwater into the substrate or prevent it completely (PIG 1957). The area has the shape of a plateau, which is primarily inclined towards the west and southwest, towards the Bierawka River valley. The study area has been transformed owing to the exploitation of mineral resources and the development of towns and cities.

\section{Results}

The anthropogenic water bodies present in the examined area can be divided into four types depending on their origins, in line with the classification proposed by Jankowski (1986). In 1827 and 1828, there were seven water bodies with a total surface area of 19 hectares (Table 1). These were reservoirs impounded by dams in the valleys of the Knurówka and Bierawka Rivers and also on the Krywałdzki and Szczygłowicki Streams (Fig. 2). From 1928 to 1936, there were 14 small water bodies in Knurów with a total surface area of 12 hectares. Apart from nine reservoirs impounded by dams, there were also two industrial tanks used by the Knurów coal mine and three flooded mineral workings. The area covered by water bodies in 1960 was the lowest of all the studied periods and only came to 10 hectares. During this time, water bodies of the following origins were present in the examined area: two reservoirs impounded by dams, two in subsidence basins and hollows, six flooded mineral workings and three industrial tanks. In 1993, there were 63 water bodies in town with a total surface area of 139 hectares. The most numerous among them were water bodies in subsidence basins and hollows (37), which outnumbered industrial tanks (21) and flooded mineral workings (5). All reservoirs impounded by dams had been dismantled by that time (Table 1 ).

In 2011, lentic waters occupied around $127 \mathrm{hec}-$ tares in the study area (ca. $4 \%$ of the town area). At that time, there were 29 industrial tanks (fire-fighting and sedimentation tanks, etc.) and 38 water bodies in subsidence basins and hollows. Water was also retained in three flooded mineral workings (Fig. 3).

\section{Discussion}

In the study area the earliest water bodies were reservoirs impounded by dams, which were construct- 


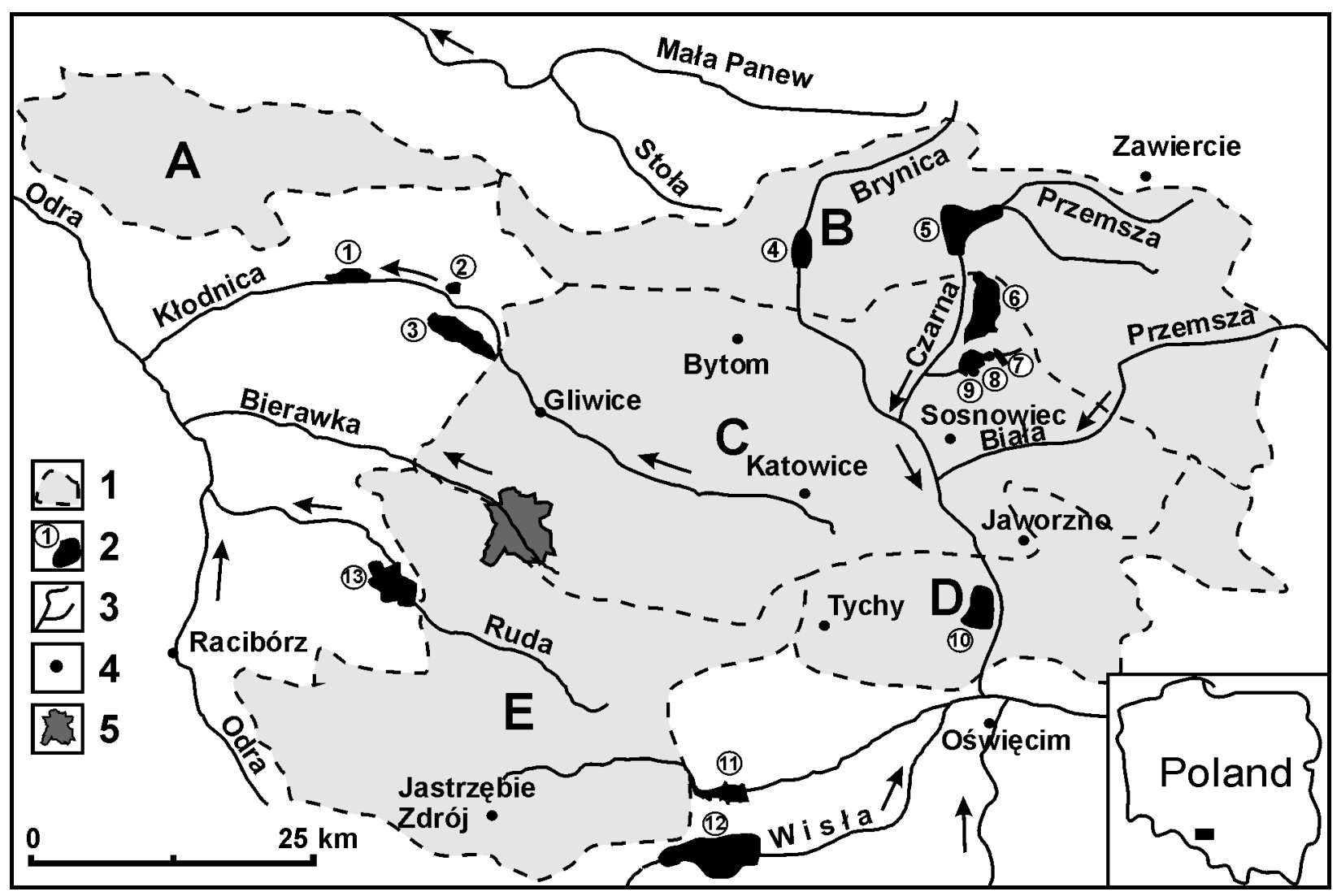

Fig. 1. Location of the study area against the physiogeographical units (Kondracki 2002): 1 - Mesoregions of the Silesian Upland (A - Chełm, B - Hummock of Tarnowskie Góry, C - Katowice Upland, D - Jaworzno Hills, E - Rybnik Plateau); 2 - more important water reservoirs (1 - Pławniowice, 2 - Dzierżno Małe, 3 - Dzierżno Duże, 4 - Kozłowa Góra, 5 - Przeczyce, 6 - Kuźnica Warężyńska, 7 - Pogoria I, 8 - Pogoria II, 9 - Pogoria III, 10 - Dziećkowice, 11 - Łąka, 12 - Goczałkowice, 13 - Rybnik); 3 - river network; 4 - more important towns, 5 - border of Knurów

Table 1. Occurrence of anthropogenic types of water reservoirs in Knurów in 1827-2011

\begin{tabular}{|c|c|c|c|c|c|c|}
\hline \multirow{2}{*}{\multicolumn{2}{|c|}{ Genetic types of water reservoirs }} & \multicolumn{5}{|c|}{ Years } \\
\hline & & $1827-1828$ & $1928-1936$ & 1960 & 1993 & 2011 \\
\hline \multirow{4}{*}{ Dams } & Number & 7 & 9 & 2 & 0 & 0 \\
\hline & [\%] & 100.0 & 64.3 & 15.4 & 0.0 & 0.0 \\
\hline & Area [ ha ] & 19.0 & 6.5 & 1.3 & 0 & 0 \\
\hline & {$[\%]$} & 100.0 & 54.2 & 13.3 & 0.0 & 0.0 \\
\hline \multirow{4}{*}{ Mineral workings } & Number & 0 & 3 & 6 & 5 & 3 \\
\hline & {$[\%]$} & 0.0 & 21.4 & 46.1 & 7.9 & 4.3 \\
\hline & Area [ ha ] & 0 & 3.0 & 3.8 & 5.7 & 4.6 \\
\hline & {$[\%]$} & 0.0 & 25.0 & 37.8 & 4.1 & 3.6 \\
\hline \multirow{4}{*}{ Industrial } & Number & 0 & 2 & 3 & 21 & 29 \\
\hline & {$[\%]$} & 0.0 & 14.3 & 23.1 & 33.4 & 41.4 \\
\hline & Area [ ha ] & 0 & 2.5 & 3.6 & 32.3 & 32.0 \\
\hline & [\% ] & 0.0 & 20.8 & 35.6 & 23.2 & 25.2 \\
\hline \multirow{4}{*}{$\begin{array}{l}\text { Subsidence basins } \\
\text { and hollows }\end{array}$} & Number & 0 & 0 & 2 & 37 & 38 \\
\hline & [\% ] & 0.0 & 0.0 & 15.4 & 58.7 & 54.3 \\
\hline & Area [ ha ] & 0 & 0 & 1.3 & 101.0 & 90.4 \\
\hline & [\% ] & 0.0 & 0.0 & 13.3 & 72.7 & 71.2 \\
\hline \multirow{2}{*}{ Total } & Number & 7 & 14 & 13 & 63 & 70 \\
\hline & Area [ ha ] & 19.0 & 12.0 & 10.0 & 139.0 & 127.0 \\
\hline
\end{tabular}




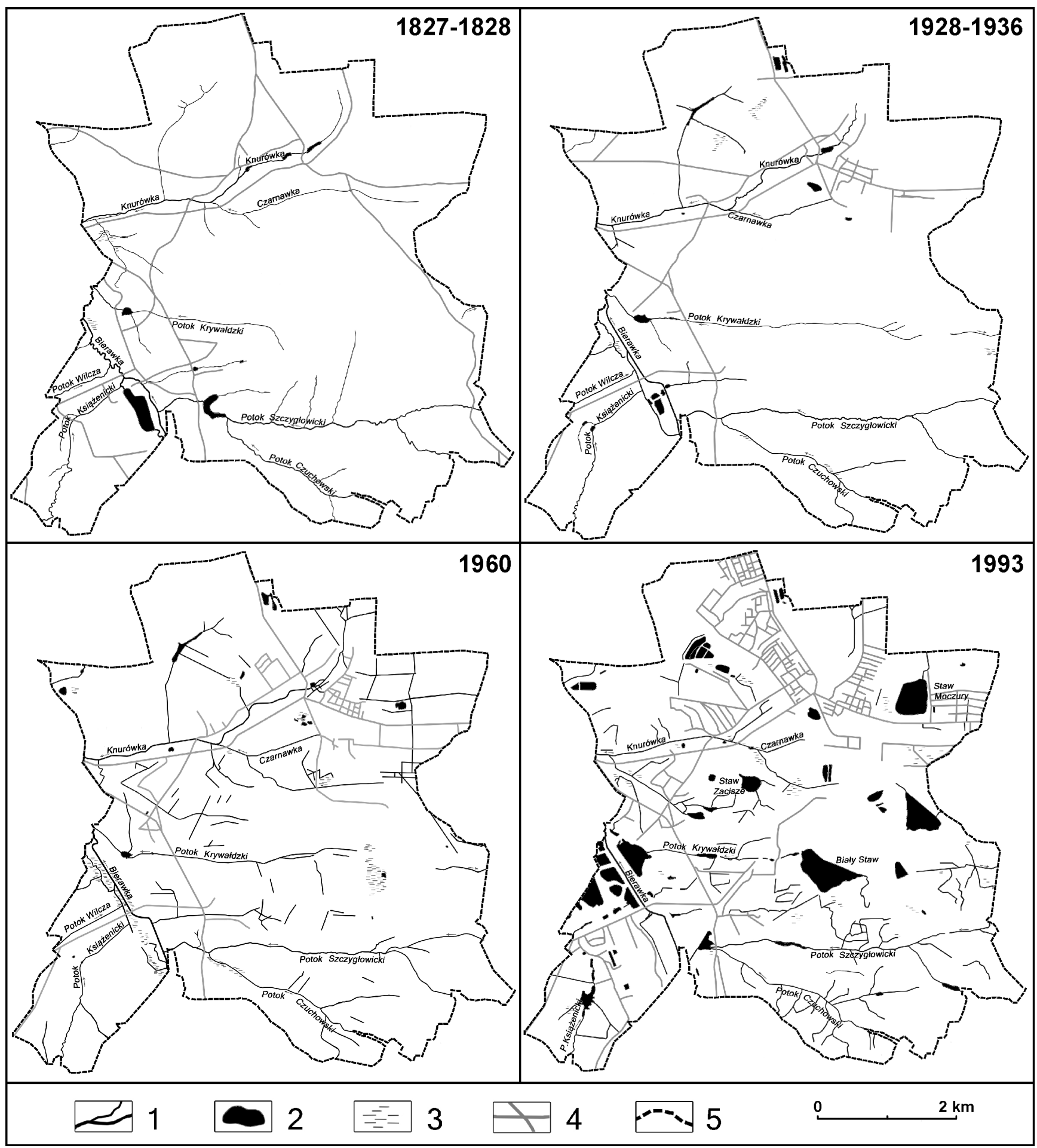

Fig. 2. Transformation of anthropogenic water reservoirs in Knurów in 1827-1993: 1 - river network, 2 - water reservoirs, 3 - wetlands, 4 - roads, 5 - border of town 


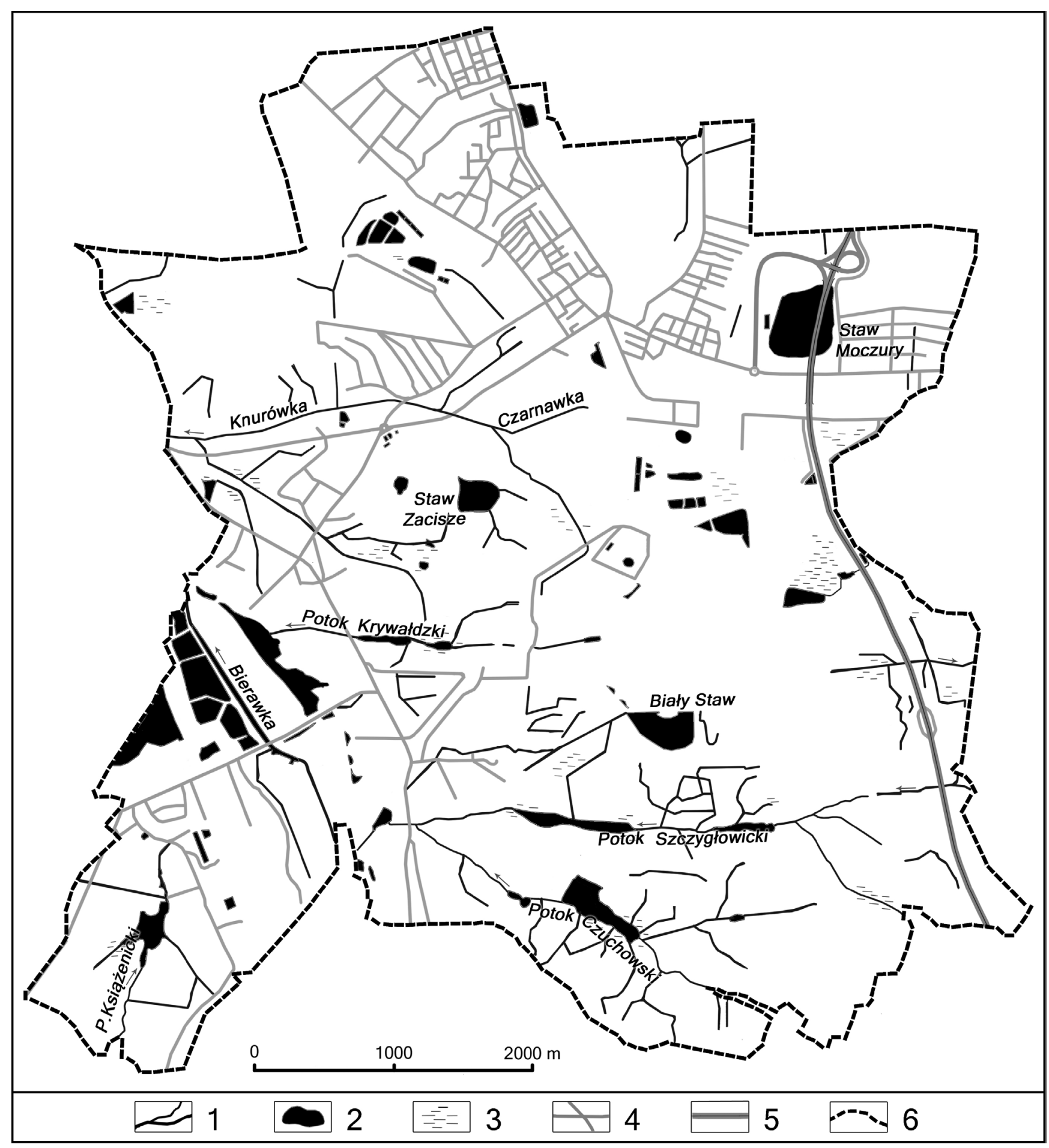

Fig. 3. Surface water in the area of Knurów in 2011: 1 - river network, 2 - water reservoirs, 3 - wetlands, 4 - roads, 5 - highway, 6 - border of town 
ed by damming river valleys. Those were first recorded in the 1596 Urbarium, which stated that there were four such reservoirs in Krywałd, a district of Knurów; they were used to farm fish (Koziełek 1937). Reservoirs of this type have existed for quite a long time in the Silesian Upland. Such hydrological facilities were constructed in pre-determined locations and were assigned precise functions at the time of their construction. In historical times, those were water bodies with limited retention capabilities. The water accumulated therein was most often used to power watermills and sawmills and also to farm fish and crayfish (Czaja 1999). There are currently no reservoirs impounded by dams in Knurów. Similar trends with respect to such reservoirs can be observed in many other cities and towns in the Silesian Upland, e.g. Bytom (Jankowski 1991), Sosnowiec (Czaja 1994) or Katowice (Czaja 1995). There are relatively few such water bodies in the Silesian Upland and they are mostly situated outside built-up areas. They have various surface areas and water retention capacities. The largest such reservoir is the Kozłowa Góra, with a maximum surface area of $5.9 \mathrm{~km}^{2}$ and a capacity of $0.0153 \mathrm{~km}^{3}$, was constructed on the Brynica River. Another one is the Przeczyce Reservoir, which was constructed by damming the Czarna Przemsza River gorge. After the river had been dammed, a reservoir was created with a surface area of $5.1 \mathrm{~km}^{2}$ and a capacity of $0.0207 \mathrm{~km}^{3}$. Other reservoirs of this type within the Silesian Upland have far smaller water retention capacities (Rzętała and Jaguś 2012).

At the beginning of the $20^{\text {th }}$ century, flooded mineral workings started to emerge in the study area (Table 1); these were associated with the flooding of sites where minerals had been excavated. In Knurów, the most frequently mined material was used to produce bricks in the local brickworks. Owing to the thickness of its deposits and the manner in which they were excavated, these water bodies are small and usually less than ten metres deep. Their average surface area during the study period was around 1 ha. In the examined area, only three contemporary water bodies of this type with a total surface area of 4.6 ha were found. In the Silesian Upland, water bodies are most often formed in sites where sand, clay, limestone, dolomite as well as zinc and lead ores and coal were mined. The surface area of such water bodies varies widely from a few dozen square metres (e.g. $85 \mathrm{~m}^{2}$ in Bytom) to a few square kilometres (e.g. Dziećkowice $7.1 \mathrm{~km}^{2}$ ). Many small water bodies can be found in the depressions that were left after the medieval exploita- tion of zinc and lead ores on the boundary of Bytom and Tarnowskie Góry. Water-filled holes that are remnants of open-pit coal mining are found in Dąbrowa Górnicza, Jaworzno, Katowice, Ruda Śląska, Zabrze and Mikołów (Rzętała 2008). Water bodies located in sand workings are a relatively new feature in the geographical environment of the area. As one of the first, established in 1938, was reservoir Dzierżno Małe. They have varying surface areas and some of them are among the largest in the Silesian Upland. Dziećkowice, Rogoźnik, Balaton and Sosina are among the notable ones. Water bodies situated in the Dąbrowa Basin, and the Kuźnica Warężyńska Lake, which is among the largest water bodies in Poland, are included in this group as well. Large water bodies of this origin can also be found within the Kłodnica River hydrological complex: the Dzierżno Duże, Dzierżno Małe and Pławniowice, which lie just outside the boundaries of the Silesian Upland (Machowski et al. 2006).

At the same time, the first water bodies constructed in order to meet industrial and municipal needs appeared in Knurów (Table 1). These can be described as reservoirs directly associated with the manufacturing cycles of the adjoining industrial plants. From the point of view of their origins, they form quite a diverse group. In this group, sedimentation tanks for mine water, washery effluent, backfill and cooling water, bathing pools and fire-fighting tanks, tanks at sewage treatment plants, industrial and municipal water tanks and also other facilities of lesser significance can be found. In Knurów, the number and surface area of such water bodies rose steadily during the studied period. Currently, they account for slightly more than $40 \%$ (29) of the total number of lentic water bodies within town boundaries and ca. 25\% (32 ha) of overall surface area (Table 1). With progressing industrialisation and urbanisation during the past 200 years, a significant increase in the number of such water bodies was also observed in other parts of the Silesian Upland. According to Czaja (1999), in the early $20^{\text {th }}$ century they accounted for $5.6 \%$ of the total number and by the end of the $20^{\text {th }}$ century their share had increased to slightly over $41 \%$. In the mid-1990s, owing to their relatively small surface areas, they accounted for ca. $20 \%$ of total area of lentic waters in the Katowice conurbation (Czaja 1999).

In Knurów, water bodies in subsidence basins and hollows can also be found. Water bodies of this type were the last to emerge in the study area - the first ones only formed in the 1960s. After more than 30 
years, their numbers increased considerably and they have been the dominant water body type in Knurów since 1993. In 2011, they accounted for $54.3 \%$ of the total number and $71.2 \%$ of the overall area of lentic water bodies in town (Table 1). A similar trend can be observed in other parts of the Silesian Upland that are subject to rock mass deformations caused by subsurface mineral mining. The effects of subsidence and the formation of depressions can be observed in an area of more than $1,000 \mathrm{~km}^{2}$, mainly within the Katowice Upland, but also on the Rybnik Plateau. After minerals had been extracted, empty spaces are left underground. As a result of developing vertical movements, rock masses slowly move to fill the cavities formed. A consequence of such migrations are morphological changes that manifest themselves on the surface as the deformation of layers, land subsidence and the formation of depressions (Żmuda 1973). The subsidence process only initiates the formation of depressions on the land surface. In order for water bodies to form in places where the ground has subsided, certain conditions must be fulfilled. Within the subsiding rock formation, impermeable formations must be present at relatively shallow depths that effectively stop the water infiltrating into the ground. The subsidence basin formed forces groundwater to flow towards its central part, which leads to the elevation of the water table relative to ground surface. Owing to the continuous subsidence process and the flow of groundwater as well as the sheet flow of rainwater and meltwater in the initial stage of development of the subsidence basin, the ground becomes waterlogged. Finally, the accumulated water reaches the ground level and fills the subsidence basin, resulting in the formation of a water body (Machowski 2010). The appearance of newly formed water bodies is modified by human activity to a large extent. Changes in such water bodies are also caused by reclamation work, which is aimed at their elimination by filling them up with earth; this can be observed e.g. in Knurów districts of Krywałd and Szczygłowice and within the central site where mining waste is stored. These water bodies quite often present major problems due to the inadequate quality of the water retained, their small surface areas and capacities as well as the continuous land deformation processes. Water bodies in subsidence basins and hollows assimilate with the surrounding environment very quickly. The hydrological processes occurring when such water bodies are formed as a consequence of changes in water conditions are caused by orographic transfor- mations and are accompanied by numerous changes in the biotope and biocenosis alike (Jankowski et al. 2001). Rare plant species emerge around such water bodies. These types of areas are legally protected; one example is the "Żabie Doły" landscape and nature protected complex on the boundary of Bytom and Chorzów. The water bodies described are a dynamic component of the natural environment. They formed in the past, are forming currently and will continue to form against human will, causing considerable damage, and land deformation processes will continue several decades after subsurface mining has ended (Machowski et al. 2012).

Currently, water bodies account for ca. $4 \%$ of the town area. This is a figure slightly higher than the average lake density (water body density) in the Upper Silesian Anthropogenic Lake District (USALD), which is $2.1 \%$. The highest lake density (at $19.2 \%$ ) is characteristic of USALD boundaries and related to the presence of large reservoirs impounded by dams and flooded mineral workings. The lowest figure is just $0.003 \%$ and pertains to its central part ((Rzętała 2008)). Moreover, lake density in Knurów is higher than the overall figure for Poland, which is $0.9 \%$. It is also higher than the figures typical of areas with the highest concentration of lakes in Poland as stated by Choiński (2007), i.e. the Masurian Lake District, Pomeranian Lake District and Greater Poland-Kujawy Lake District. Within these lake districts, areas with much higher lake densities can obviously be found, e.g. the catchment of the Wegorapa River where the Great Masurian Lakes are situated.

\section{Conclusion}

In Knurów, no natural lakes have been present for the last 200 years. This is mainly due to the old glacial landscape of the area in question. Despite unfavourable environmental conditions, from several up to several dozen water bodies were present in the area in any studied period. These formed as a result of deliberate human projects (e.g. reservoirs impounded by dams, flooded mineral workings) but also as unintended effects of new economic activity in the region (water bodies in subsidence basins and hollows). The transformations of those water bodies have been characteristic of the entire Silesian Upland region. In the first half of the $19^{\text {th }}$ century, when agriculture prevailed, only reservoirs impounded by dams were present. As industry and coal mining developed, reservoirs im- 
pounded by dams gradually disappeared and were replaced by flooded mineral workings, industrial tanks and water bodies forming in subsidence basins and hollows. The number of anthropogenic water bodies increased markedly at the end of the second half of the $20^{\text {th }}$ century. Currently, they account for ca. $4 \%$ of the town area. The prevailing type are water bodies in subsidence basins and hollows (38), which account for $71.2 \%$ of water surface area. The second most numerous type are industrial tanks (29), which account for $25.2 \%$ of surface area. In 2011, only three flooded mineral workings were present in Knurów (3.6\% of surface area) with the last reservoirs impounded by dams dismantled between1960 and 1993.

\section{References}

Choiński A., 2007, Limnologia fizyczna Polski (Physical limnology of Poland), Wyd. Nauk. UAM, Poznań, p. 547 (in Polish).

Czaja S., 1994, Zmiany zagospodarowania przestrzennego i powierzchniowej sieci hydrograficznej na obszarze miasta Sosnowca w latach 1783-1985 (Changes in land use and surface hydrographic network in the city of Sosnowiec in the years 1783-1985), Rocz. Sosnowiecki 3: 6884 (in Polish).

Czaja S., 1995, Zmiany użytkowania ziemi i powierzchniowej sieci hydrograficznej na obszarze miasta Katowice w latach 1801-1985 (Changes in land utilization and surface hydrographic net in the area of Katowice town in the years 1801-1985), Geographia. Studia et Dissertationes UŚ 19: 7-23 (in Polish).

Czaja S., 1999, Zmiany stosunków wodnych w warunkach silnej antropopresji (na przykładzie konurbacji katowickiej) (Changes in water relations under the conditions of strong anthropopression (a case study of Katowice conurbation), Wyd. UŚ, Katowice, p. 192 (in Polish, English summary).

Dulias R., 2011, Impact of mining subsidence on the relief of the Rybnik Plateau, Poland, Z. Geomorphol. 55(Suppl. 1): 25-36.

Jankowski A.T., 1986, Antropogeniczne zmiany stosunków wodnych na obszarze uprzemysłowionym i urbanizowanym (na przykładzie Rybnickiego Okręgu Węglowego) (Anthropogenic changes in the water relations in the industrialized and urbanized area (example of the Rybnik Coal District), Wyd. UŚ, Katowice, p. 280 (in Polish).

Jankowski A.T., 1991, Występowanie antropogenicznych zbiorników wodnych na terenie Bytomia w okresie 1811-1989 (Anthropogenic water reservoirs in Bytom area in the period 1811-1989), Kształt. Środ. Geogr. Ochr. Przyr. Obsz. Uprzem. Zurban. 3: 21-30 (in Polish, English summary).
Jankowski A.T., Molenda T., Rzętała M., 2001, Reservoirs in subsidence basins and depression hollows in the Silesian Upland - selected hydrological matters, Limnol. Rev. 1: 143-150.

Kondracki J., 2002, Geografia regionalna Polski (Regional Geography of Poland), PWN, Warszawa, p. 440 (in Polish).

Koziełek A., 1937, Knurów i Krywałd: Kronika na tle historii ziemi gliwickiej (Knurów and Krywałd: The chronicle on the background of the history of Gliwice Land), Monogr. TPNŚ 4, Selbstverl. des Verf., Katowice, p. 180.

Machowski R., Rzętała M.A., Rzętała M., 2006, Procesy i formy brzegowe $\mathrm{w}$ obrębie jeziora poeksploatacyjnego w początkowym okresie funkcjonowania na przykładzie zbiornika Kuźnica Warężyńska (Shore processes and landforms within post-exploatation lake in the initial stage of functioning, a case study of the Kuźnica Warężyńska water reservoirs), Kształt. Środ. Geogr. Ochr. Przyr. Obsz. Uprzem. Zurban. 37: 29-36 (in Polish, English summary).

Machowski R., Rzetala M. A., Rzetala M., 2012, Transformation of lakes in subsidence basins in the Silesian Upland (Southern Poland), Proc. of the $12^{\text {th }}$ International Multidiscyplinary Scientific Geoconference SGEM 2012, Vol. 3: 895-901.

Machowski R., 2010, Przemiany geosystemów zbiorników wodnych powstałych w nieckach osiadania na Wyżynie Katowickiej (Transformations of geosystems of water reservoirs originated in subsidence depressions (a case study of the Katowice Upland), Wyd. UŚ, Katowice, p. 178 (in Polish).

Pełka-Gościniak J., 2006, Restoring nature in mining areas of the Silesian Upland (Poland), Earth Surf. Process. Landforms 31(13): 1685-1691.

[PIG] Państwowy Instytut Geologiczny (Polish Geological Institute), 1957, Szczegółowa Mapa Geologiczna Polski w skali 1:50 000, Arkusz 941: Gliwice (Detailed Geological Map of Poland in 1:50 000 scale, Sheet 941: Gliwice).

Rzętała M., Jaguś A., 2012, New lake district in Europe: origin and hydrochemical characteristics, Water Environ. J. 26(1): 108-117.

Rzętała M., 2008, Funkcjonowanie zbiorników wodnych oraz przebieg procesów limnicznych w warunkach zróżnicowanej antropopresji na przykładzie regionu górnośląskiego (Functioning of water reservoirs and the course of limnic processes under conditions of varied anthropopression, a case study of Upper Silesian Region), Wyd. UŚ, Katowice, p. 172. (in Polish, English summary) Żmuda S., 1973, Antropogeniczne przeobrażenia środowiska przyrodniczego konurbacji górnośląskiej (Anthropogenic transformation of the natural environment of the Upper Silesian conurbation), Śląski Inst. Nauk., Katowice, p. 211 (in Polish). 